\title{
Short-term changes in the energy balance of Venerupis corrugatus (Bivalvia) in relation to tidal availability of natural suspended particles
}

\author{
J. M. E. Stenton-Dozey, A. C. Brown \\ Zoology Department, University of Cape Town, Rondebosch 7700, South Africa
}

\begin{abstract}
This study further investigates the finding that a near doubling in clearance rates of Venerupis corrugatus correlated with a significant increase in natural particle concentration and silt load at high tide. At this time full extension of the siphons and open valves indicated increased pumping activity, whilst copious production of pseudofaeces showed that more filtered material was being rejected at high tide. After considering particle rejection, net organic ingestion $\left(I R, \mathrm{mg} \mathrm{h}^{-1}\right)$ was related to clam size ( $W, g$ dry $w t$ ) by the allometric equations: $I R=5.821 W^{0.649}$ at low and $I R=7.867 W^{0.724}$ at high tide. This difference was significant, as was that between quantities of pseudofaeces produced $\left(\mathrm{mg} \mathrm{h} \mathrm{h}^{-1}\right)$ at low $\left(2.498 \mathrm{~W}^{0447}\right)$ and high tide $\left(4.686 W^{0.582}\right)$. Particle sorting efficiencies were sizedependent, ranging from $69 \%$ for large clams to $63 \%$ for juveniles at low tide and from 71 to $54 \%$ at high tide. Thus with an increase in the particle load, sorting efficiency in adult clams changed little while that in juveniles was depressed. Absorption efficiency declined significantly from $49 \%$ at low tide to $41 \%$ on the flood tide. Respiration and excretion rates did not differ significantly between tides; common regressions were $R\left(\mathrm{ml} \mathrm{O}_{2} \mathrm{~h}^{-1}\right)=0.785 W^{0.721}$ and $U\left(\mu \mathrm{g} \mathrm{NH}_{4}-\mathrm{N} \mathrm{h}^{-1}\right)=2.733 W^{1.343}$. Nonetheless potential for production $(P)$ was significantly greater at high tide, being described by $P\left(J h^{-1}\right)=$ $15.751 W^{0696}$ compared with $P=12.271 W^{0.695}$ at low tide. Resultant net growth efficiencies were some 10 percentiles higher ( 49 to $53 \%$, depending on size) relative to low tide ( 37 to $42 \%$ ), a difference indicating successful and immediate exploitation of the tidally induced improvement in food supply. Elevated efficiencies were realised not by changes in absorption efficiency, respiration or excretion, but by an increase in clearance rates which, even after being balanced against a rise in pseudofaeces production, resulted in greater net organic ingestion at high tide. Short-term increases in production potential thus correlated with cyclic patterns of food supply. It is debated whether such production is a result of innate physiological regulation depending on nutritional needs or as a consequence of autonomous processes of water pumping and filtration efficiency.
\end{abstract}

KEY WORDS: Clam $\cdot$ Energy balance $\cdot$ Intertidal $\cdot$ Natural suspended particulates $\cdot$ Clearance Ingestion

\section{INTRODUCTION}

In studies on bivalve energetics, there have consistently been 2 major ambiguities in extrapolating laboratory-based data on energy budgets to the natural environment. The first of these relates to diet and the second to natural temporal influences on food supply. While it is convenient to use an easily accessible food such as algae cultured in the laboratory or mixtures of algae and inert material to vary nutrient value, it is more meaningful in terms of extrapolating laboratory energy budgets to the field situation to use food derived from the natural habitat. Such food, for example powdered saltmarsh leaves (Lucas \& Newell 1984, Newell \& Langdon 1986) and detritus from kelp fronds (Stuart 1982), would reflect natural texture, palatability, composition and energy content (Wright et al. 1982, Newell \& Jordan 1983, Lucas et al. 1987, Matthews et al. 1989, Stenton-Dozey 1989, Navarro et al. 1992, Urban \& Kirchman 1992).

The second ambiguity, that of temporal influences on energy balance, has received little attention. Where it has been addressed, the focus has been on the effect of seasonal fluctuations in food concentration (Griffiths \& 
King 1979, Griffiths 1980) or episodic events such as upwelling (Stuart \& Klumpp 1984, Seiderer \& Newell 1985). However, these studies did not use natural diets or consider coinciding temporal changes in food quality. In this regard Kiørboe et al. (1981), Riisgård \& Randløv (1981), Hawkins \& Bayne (1985) and Hawkins et al. (1985) researched seasonal patterns of food processing and growth in Mytilus edulis.

As a contribution towards the understanding of bivalve energy budgets based on fluctuations in diets that are wholly natural, we undertook a study of Venerupis corrugatus (Gm.), a filter-feeding, burrowing clam found in sheltered intertidal areas of South Africa. Experimental design focused on the tidal availability and composition of natural suspended particulates in a rock pool with a sandy substrate inhabited by $V$. corrugatus. An earlier paper (Stenton-Dozey \& Brown 1992) reported analyses of seawater samples, collected hourly during a $13 \mathrm{~h}$ spring tidal cycle, for particle size, particle quantity (counts, total and organic dry wt) and quality (organic content). Maximum particle size increased from 12 to $23 \mu \mathrm{m}$ on the flood tide, while total particulate dry wt increased 4fold to a maximum of $23 \mathrm{mg} \mathrm{l}^{-1}$. Clearance rates, measured by following the decline in natural particulates in unfiltered seawater collected at low and high tide, were significantly related to tidal height and particle size plus an interaction of these 2 factors. When using high-tide water, larger particles were cleared at faster rates than in low-tide experiments, resulting in a substantial increase in the ingestion of organic material.

The present paper aims to identify any short-term increase in production potential $(P=$ somatic growth, reproduction and/or deposition of energy reserves) of Venerupis corrugatus following a tidally induced rise in food supply. Rates of ingestion derived from indirect measurements of clearance rates of natural particulates are balanced against rates of ammonia excretion, defaecation and respiration. These data are discussed with reference to the recent debate on whether production potential in a bivalve is determined by innate physiological processes (Hawkins et al. 1985, Bayne et al. 1989, Bayne \& Hawkins 1990) or simply by the rate at which the filtration mechanism processes particulate material (Jørgensen 1990).

\section{MATERIALS AND METHODS}

Rock-pool environment. The study site was located at Bloubergstrand, just north of Cape Town, on the west coast of South Africa, and comprised a large rock pool with a sandy bottom. At low tide the pool is isolated from the sea by a rocky outcrop, beyond which lies an extensive kelp bed. Temperature and oxygen content of the rock pool were monitored every hour between low and high tides. Water warmed up from 13 to $18^{\circ} \mathrm{C}$ while the pool was isolated ( 4 to $5 \mathrm{~h}$ ), falling to $14^{\circ} \mathrm{C}$ after inundation. Oxygen levels ranged from 8 to $10 \mathrm{mg} \mathrm{l}^{-1}$, supersaturation being reached at high tide.

Experimental clams were collected in summer when a light southeasterly wind prevailed. At the same time, $50 \mathrm{l}$ of rock-pool water was sampled at low and high tides, when low and high particle densities could respectively be expected (Stenton-Dozey \& Brown 1992). Clams were maintained in rock-pool water overnight so they could feed on natural particulates before experiments were conducted the following day.

Clearance rates. Detailed methodology can be found in Stenton-Dozey \& Brown (1992). Briefly, clearance rates were determined indirectly by measuring the decline in natural particle densities within $1 \mu \mathrm{m}$ diameter size categories. Two sets of experiments were conducted, one using unfiltered seawater collected at low tide, and the other water collected at high tide. The total number of particles, including bacteria, cleared from suspension was calculated by summation of numbers of particles in each size category before and after each experimental period. These data were then used in the equations of Coughlan (1969) to calculate overall clearance rates for clams ranging in size from 26 to $867 \mathrm{mg}$ soft tissue dry wt (17 to $53 \mathrm{~mm}$ shell length). Results are presented as allometric equations relating body weight to clearance rate.

Ingestion rates. Ingestion rates as $\mathrm{mg}$ inorganic and/or organic dry wt ingested $\mathrm{h}^{-1}$ individual ${ }^{-1}$ were calculated from mean particle concentration $x$ clearance rate. A distinction was made between gross ingestion (i.e. the particulate quantity cleared from suspension) and net ingestion (the quantity entering the mouth after rejected material has been released as pseudofaeces). This was achieved by subtracting the mean total and organic dry wt of pseudofaeces produced $\mathrm{h}^{-1}$ from the overall quantity of material ingested $\mathrm{h}^{-1}$. Once again ingestion rates were related to body weight in allometric equations.

Absorption efficiencies. The ash-ratio method (Conover 1966) was used to estimate absorption efficiencies as given by the following formula:

$$
A E=\frac{f-e}{(1-e) f} \times 100
$$

where $A E=$ absorption efficiency; $f=$ organic fraction of food; and $e=$ organic fraction of faeces.

Faeces were collected immediately after they emerged from the exhalant siphon, suctioned onto ashed $\left(460^{\circ} \mathrm{C}\right.$ for $\left.6 \mathrm{~h}\right)$, pre-weighed $25 \mathrm{~mm}$ Whatman $\mathrm{GF} / \mathrm{F}$ filters and rinsed with ammonium formate to remove salts. These filters were dried at $60^{\circ} \mathrm{C}$ for $2 \mathrm{~d}$ to obtain total dry wt, then ashed at $460^{\circ} \mathrm{C}$ for $20 \mathrm{~h}$, 
reweighed, and the organic content of faeces determined by difference. The Conover ratio implicitly assumes non-selective feeding. However, during experiments Venerupis corrugatus produced copious amounts of pseudofaeces, which constitute the rejection of some organic material after particles have been filtered but not yet ingested. This necessitated estimating an organic fraction for $f$ in the Conover ratio which was the balance between the organic fraction filtered and that lost in pseudofaeces. This was possible by collecting all pseudofaeces produced during experiments and determining their total weight and organic content.

Metabolic expenditure. Rates of excretion were estimated by measuring ammonium $\mathrm{N}$. During and after feeding experiments, replicate $5 \mathrm{ml}$ samples were taken at $1 \mathrm{~h}$ intervals for $5 \mathrm{~h}$ for an indophenol-blue spectrophotometric determination of ammonia as modified from Koroleff (1976). Excretion rates were calculated over $4 \mathrm{~h}$ from regression slopes of $\mu \mathrm{g} \mathrm{NH}_{4}-\mathrm{N}$ clam $^{-1}$ against time $(\mathrm{h})$ for different body sizes.

Aerobic respiration rates were measured in a flowthrough respirometer, fitted with YSI (Yellow Springs Instrument Co.) dissolved-oxygen probes and housed in a constant temperature room set at $15^{\circ} \mathrm{C}$. Unfiltered seawater collected from the pool was used in the respirometer so that respiration rates would reflect filtration activity. Seawater flowed from an upper reservoir through 4 respiration chambers into a bottom reservoir, from where it was returned to the top reservoir via a pump. The chambers, fitted with YSI probes, could be shut off from flowing seawater by tourniquet valves on the inlet and outlet hoses. At all times these chambers were submerged to prevent air leakage, while magnetic stirrers ensured circulation within. The probes were linked to an oxygen meter interfaced to a computer programmed to regress the decline in oxygen content against time.

Production potential. Rates of respiration $(R)$ and excretion $(U)$ were balanced against the absorbed ration $(A b=$ ingestion rate $\times$ absorption efficiency) to arrive at the potential for production (growth, reproduction and deposition of energy reserves $=P$, in $\mathrm{J} \mathrm{h}^{-1}$ ) for standardised weights of clams. $P$ is substituted for the more commonly used term 'scope for growth' (SFG) in light of recent interpretive criticisms (Jørgensen 1990). For metabolic expenditure the following energy conversions were used: $1 \mathrm{ml} \mathrm{O}_{2}=20.08 \mathrm{~J}$ (Gnaiger 1983) and $1 \mathrm{mg} \mathrm{NH}_{4}-\mathrm{N}=24.87 \mathrm{~J}$ (Elliot \& Davison 1975).

The energy of suspended particulate material was based on a ratio of $1 \mathrm{mg}$ organic dry wt $=9.72 \mathrm{~J}( \pm 0.85$, $\mathrm{n}=6$ ). This food value was determined by concentrating the filtrate of rock-pool seawater on membrane filters, scraping the filtrate onto glass slides, drying at $60^{\circ} \mathrm{C}$ for $24 \mathrm{~h}$ followed by combustion in a microbomb calorimeter. Three replicates were processed for each tidal height but since negligible differences were found, data on the energy content of particulates at low and high tide were pooled.

\section{RESULTS}

\section{Resource availability}

A detailed account of suspended material present in seawater collected at Bloubergstrand and used in feeding experiments is given in Stenton-Dozey \& Brown (1992). Briefly, summation of particle numbers, dry and organic weight from $1 \mu \mathrm{m}$ particle size classes covering a diameter spectrum of 0.6 to $12 \mu \mathrm{m}$ at low tide gave $3.4 \times 10^{9}$ particles $1^{-1}$ totaling $6.7 \mathrm{mg}$ dry wt $\mathrm{l}^{-1}$ of which $61 \%$ was organic. At high tide the spectrum expanded to include $23 \mu \mathrm{m}$ diameter particles with an increase in suspension densities to $5.6 \times 10^{9} \mathrm{l}^{-1}$ representing $9.6 \mathrm{mg}$ dry wt $1^{-1}$ with a reduced organic content of $51 \%$.

\section{Clearance and ingestion rates}

Coincident with more particulates at high tide, clearance rates were nearly double that at low tide (Fig. 1). Indeed ANOVA indicated that clearance rates were significantly affected not only by tidal height, but also by particle size as well as by an interaction between these 2 factors (Table 2 in Stenton-Dozey \& Brown 1992)

Ingestion rates (Fig. 1) are quantified as inorganic and/or organic intake ( $\mathrm{mg}$ dry $\mathrm{wt} \mathrm{h}^{-1}$ ) and also expressed in gross and net terms. Differences between these categories were used to quantify the amount of inert material filtered by Venerupis corrugatus but then rejected as pseudofaeces. A doubling of clearance rates on the flood tide resulted in a 1.5-fold increase in gross ingestion, that is from $14.0 \mathrm{mg}$ filtered $\mathrm{h}^{-1}$ at low tide to $21.2 \mathrm{mg} \mathrm{h}^{-1}$ at high tide. The gross organic yield from this material amounted to $8.5 \mathrm{mg} \mathrm{h}^{-1}$ at low tide which means that $39 \%$ of total intake was inert material; the equivalent at high tide was $11.3 \mathrm{mg} \mathrm{h}^{-1}$ and $47 \%$.

At high tide net ingestion, i.e. the amount of material entering the digestive system once refractory material had been discarded as pseudofaeces, was between 1.15 and 1.35 times that at low tide. Student $t$-testing of equality between regression coefficients (Table 1) showed that the increase in ingestion rates at high tide was significant. Increased clearance and ingestion rates were associated with the observation that the siphons of individual clams held in high-tide water were often extended and fully open for long periods whereas among clams supplied with low-tide water, 
LOW TIDE
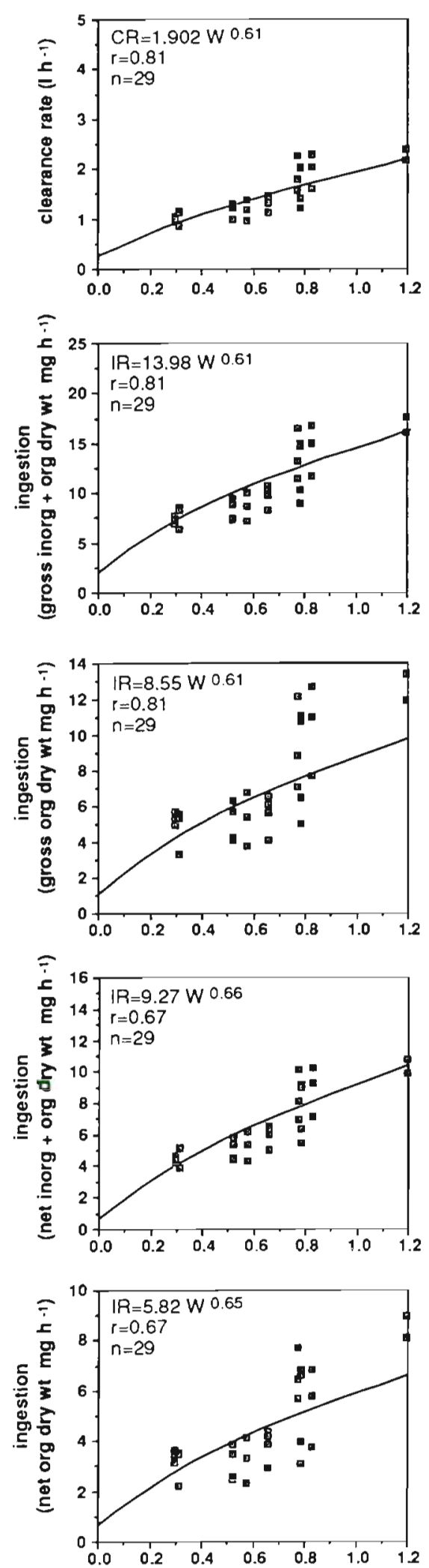

\section{HIGH TIDE}
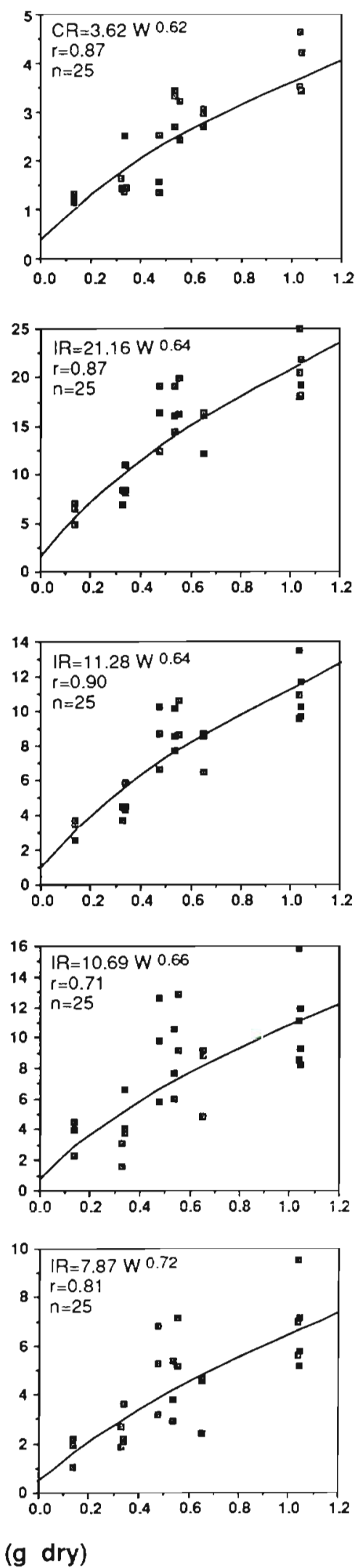

the siphons were not fully extended and closed intermittently. Valve gape was also noted to increase when high-tide water was supplied.

In association with increased particle concentration and gross ingestion rates at high tide, Venerupis corrugatus produced large quantities of pseudofaeces (Fig. 2) at rates significantly greater (Table 2) than in experiments using low-tide water. Even though more pseudofaeces was released at high tide, the proportion of organics filtered from suspension but then rejected as pseudofaeces differed little between low and high tides. Percentages were size-dependent, ranging from $31 \%$ for large clams to $37 \%$ for small ones at low tide, the equivalent at high tide being 29 to $46 \%$. These data can also be viewed in terms of the efficiency with which particles are sorted; \% efficiency $=100[1-(P / F)]$, where $P$ and $F$ represent the organic content, by weight, of material rejected in pseudofaeces and found in filtered material (Navarro et al. 1992). At low tide these efficiencies range from $69 \%$ for large $V$. corrugatus to $63 \%$ for small ones and at high tide, from 71 to $54 \%$. This indicates that with the increased particle load at high tide. sorting efficiency in adult clams changed little while that of juveniles was depressed.

Absorption efficiencies, which were calculated from the net organic fraction ingested by Venerupis corrugatus and which therefore accounted for pseudofaeces production, averaged $49 \pm 7 \%$ at low tide $(\mathrm{n}=9)$ and 41 $\pm 5 \%(n=9)$ at high tide. A 2-sample $t$-test (Zar 1984) identified a significant difference between these means $(t=2.813, n=18,0.01<p<0.05)$. The

Fig. 1 Venerupis corrugatus. Scatter plots of original data on clearance rates $\left(1 \mathrm{~h}^{-1}\right)$ and ingestion rates (mg inorganic and/or organic dry $w t h^{-1}$ ) in relation to body wt (mg dry wt) of clams at low and high tide. Superimposed on these data are graphs depicting allometric equations in Table 1 
Table 1 Venerupis corrugatus. Student t-testing of equality between regression coefficients of allometric equations for ingestion rates at low and high tide as given in Fig. 1 b. $b_{c}$ : common slope; $p=0.05$ (after Zar 1984)

\begin{tabular}{|c|c|c|c|c|c|c|c|c|c|}
\hline \multirow{2}{*}{$\begin{array}{l}\text { Ingestion rates } \\
\left(\mathrm{mg} \mathrm{h}^{-1}\right)\end{array}$} & \multicolumn{5}{|c|}{ Between slopes } & \multicolumn{4}{|c|}{ Between elevations } \\
\hline & $\mathrm{MS}$ & $\mathrm{SE}$ & $\mathrm{df}$ & $t$ & $b_{\mathrm{c}}$ & SS & MS & $\mathrm{df}$ & $t$ \\
\hline Gross inorg. + org. & 0.011 & 0.133 & 50 & \pm 0.289 & 0.644 & 0.358 & 0.007 & 51 & \pm 4.248 \\
\hline Gross org. & 0.011 & 0.133 & 50 & \pm 0.289 & 0.644 & 0.364 & 0.007 & 51 & \pm 4.628 \\
\hline Net inorg. + org. & 0.024 & 0.203 & 50 & \pm 0.266 & 0.661 & 1.197 & 0.024 & 51 & \pm 2.181 \\
\hline Net org. & 0.012 & 0.410 & 50 & \pm 0.409 & 0.698 & 0.658 & 0.013 & 51 & \pm 3.673 \\
\hline
\end{tabular}

increase in particle concentration, and most probably associated changes in particle sizes and composition that take place on the flood tide, appeared to depress absorption efficiency in $V$. corrugatus.

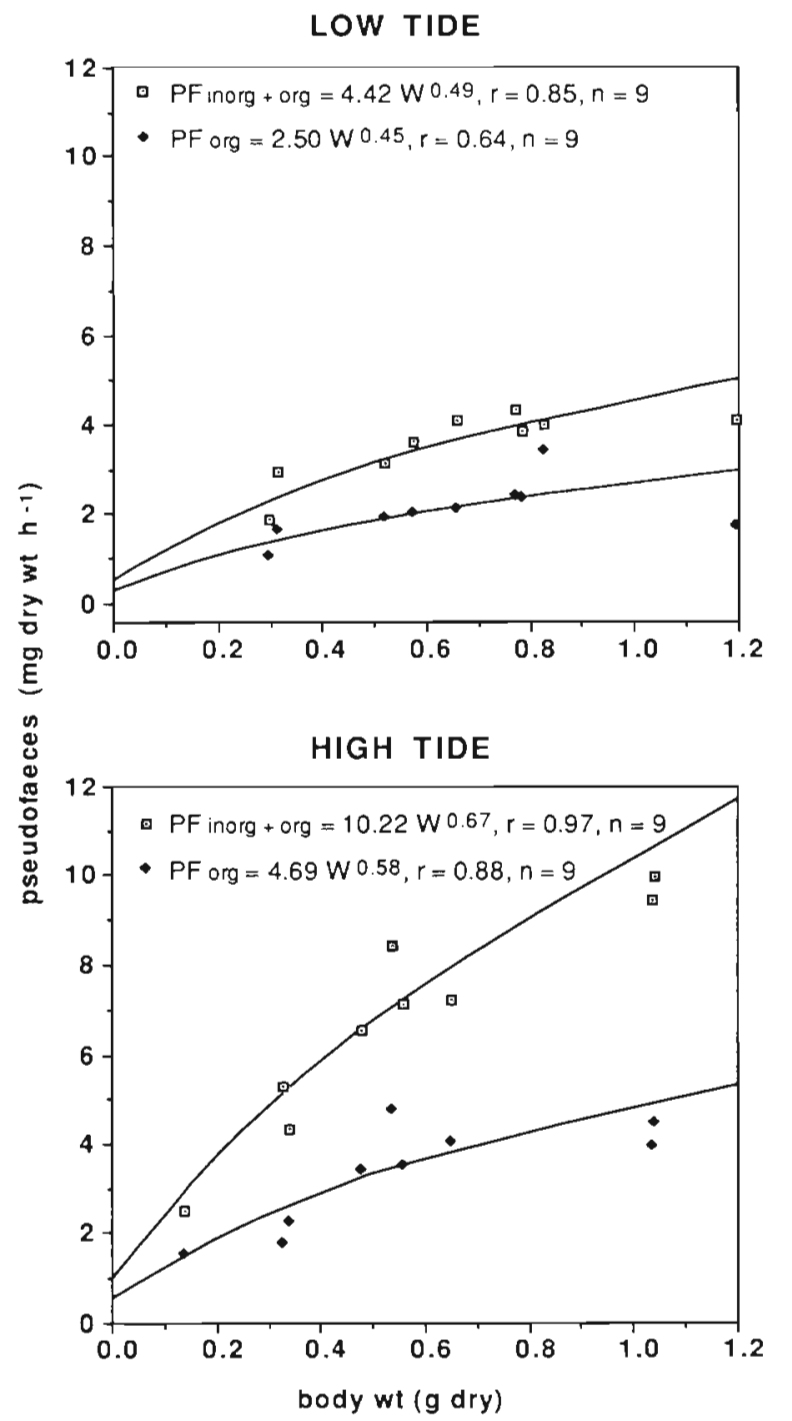

Fig. 2. Venerupis corrugatus. Scatter plots of original data on pseudofaeces production (mg dry wt) of clams at low and high tide. Superimposed on these data are graphs depicting allometric equations in Table 2

\section{Respiration and excretion}

The relationship between body wt and respiration rates $\left(R, \mathrm{ml} \mathrm{O} \mathrm{O}^{-1}\right)$ at $15^{\circ} \mathrm{C}$ was calculated as $R=$ $0.773 W^{0701}(\mathrm{r}=0.81, \mathrm{n}=22)$ at low tide and $R=$ $0.791 W^{0.731}(r=0.90, n=23)$ at high tide. However, no significant differences could be found between regression coefficients (Student $t$-test), indicating that neither the state of the tide nor, indirectly, the increase in clearance and ingestion rates associated with tidal inundation influenced respiration rates. Thus a common equation was computed (after Zar 1984): $R=$ $0.785 W^{0721}(\mathrm{r}=0.89, \mathrm{n}=45$; between slopes $t=1.38$, $0.2<\mathrm{p}<0.1$; between elevations $t=1.96, \mathrm{df}=41$, $0.1<\mathrm{p}<0.05)$.

Excretion rates $(U)$ as $\mu g \mathrm{NH}_{4}-\mathrm{N} \mathrm{h}^{-1}$ were related to body weight by $U=2.594 W^{1.316}(r=0.86, n=8)$ at low tide and $2.759 W^{1.269}(\mathrm{r}=0.96, \mathrm{n}=9)$ at high tide. Once again Student $t$-tests revealed no significant differences between elevations or weight exponents. Excretion rates could thus be expressed by 1 equation, $U=$ $2.733 W^{1.343}(\mathrm{r}=0.90, \mathrm{n}=17$; between slopes $t=0.117$, $\mathrm{df}=13, \mathrm{p}>0.5$; between elevations $t=1.913, \mathrm{df}=14$, $0.1<\mathrm{p}<0.05$ ).

\section{Production potential}

The above equations relating body weight of Venerupis corrugatus to rates of ingestion, respiration and excretion, were used to calculate an energy budget for standardised weights of clams in terms of $\mathrm{J} \mathrm{h}^{-1}$. At both low and high tide the production potential $(P)$ for all sizes of $V$. corrugatus remained positive when $R$ $+U$ were balanced against the absorbed ration $(A b)$ (Table 3). At high tide this balance was such that more energy was available for growth and reproduction than at low tide.

Allometric equations were calculated from data in Table 3: low tide, $P=12.271 W^{0.663}(\mathrm{n}=7, \mathrm{r}=0.98)$; and high tide, $P=15.751 W^{0729}(\mathrm{n}=7, \mathrm{r}=0.98)$. Given that data used to derive $P$ ( $I R$ and ration) showed significant differences, the increase in energy gain at high tide must clearly hold some significance too. Indeed, net 
Table 2. Venerupis corrugatus. Student t-testing of equality between regression coefficients of allometric equations for psendofaeces production at low and high tide as shown in Fig. 2. bc: common slope; $p=0.05$ (after Zar 1984)

\begin{tabular}{|lccccccccc|}
\hline $\begin{array}{l}\text { Pseudofaeces production } \\
\left(\mathrm{mg} \mathrm{h}^{-1}\right)\end{array}$ & $\mathrm{MS}$ & $\mathrm{SE}$ & $\mathrm{df}$ & $t$ & $b_{c}$ & \multicolumn{3}{c}{ Between elevations } \\
\hline Inorg + org. & 0.003 & 0.135 & 14 & \pm 1.394 & 0.609 & 0.054 & 0.004 & 15 & \pm 10.961 \\
Org. & 0.011 & 0.227 & 14 & \pm 0.595 & 0.535 & 0.152 & 0.011 & 15 & df \\
\hline
\end{tabular}

Table 3. Venerupis corrugatus. Energy budget $\left(\mathrm{J} \mathrm{h}^{-1}\right)$ for a selected size range of clams at low (LT) and high (HT) tide. Energy uptake calculated from net organic ingestion (IR) (Fig. 1) where $1 \mathrm{mg}$ organic dry wt $=9.72 \mathrm{~J}$. Absorbed rations $(A b)$ were based on absorption efficiencies of $49 \%$ at $\mathrm{LT}$ and $41 \%$ at $\mathrm{HT}$. Respiration $\left(R, \mathrm{ml} \mathrm{O}_{2} \mathrm{~h}^{-1}\right)=0.785 \mathrm{~W}^{0.721}$ where $1 \mathrm{ml} \mathrm{O}_{2}=20.08 \mathrm{~J}(\mathrm{Gnaiger}$ 1983). Excretion ( $U, \mu g \mathrm{NH}_{4}-\mathrm{N} \mathrm{h}^{-1}$ ) $=2.733 \mathrm{~W}^{1343}$ where $1 \mathrm{mg} \mathrm{NH}_{4}-\mathrm{N}=24.87 \mathrm{~J}$ (Elliot \& Davison 1975). $P$ : production

\begin{tabular}{|c|c|c|c|c|c|c|c|c|c|c|c|}
\hline \multicolumn{6}{|c|}{ Low tide } & \multicolumn{6}{|c|}{ High tide } \\
\hline $\begin{array}{l}\text { Body wt } \\
\text { (g dry wt) }\end{array}$ & $\begin{array}{c}I R \\
\left(J \mathrm{~h}^{-1}\right)\end{array}$ & $\begin{array}{c}A b \\
\left(J h^{-1}\right)\end{array}$ & $\begin{array}{c}R \\
\left(\mathrm{~J} \mathrm{~h}^{-1}\right)\end{array}$ & $\begin{array}{c}U \\
\left(\mathrm{~J} \mathrm{~h}^{-1}\right)\end{array}$ & $\begin{array}{c}P \\
\left(\mathrm{~J} \mathrm{~h}^{-1}\right)\end{array}$ & $\begin{array}{l}\text { Body wt } \\
\text { (g dry wt) }\end{array}$ & $\begin{array}{c}I R \\
\left(\mathrm{~J} \mathrm{~h}^{-1}\right)\end{array}$ & $\begin{array}{c}A b \\
\left(\mathrm{~J} \mathrm{~h}^{-1}\right)\end{array}$ & $\begin{array}{c}R \\
\left(\mathrm{~J} \mathrm{~h}^{-1}\right)\end{array}$ & $\begin{array}{c}U \\
\left(\mathrm{~J} \mathrm{~h}^{-1}\right)\end{array}$ & $\begin{array}{c}P \\
\left(\mathrm{~J} \mathrm{~h}^{-1}\right)\end{array}$ \\
\hline 0.1 & 12.773 & 6.239 & 2.991 & 0.003 & 2.335 & 0.1 & 14.437 & 5.919 & 2.991 & 0.003 & 2.925 \\
\hline 0.2 & 19.926 & 9.764 & 4.941 & 0.008 & 4.816 & 0.2 & 23.846 & 9.777 & 4.941 & 0.008 & 4.829 \\
\hline 0.4 & 31.201 & 15.288 & 8.142 & 0.020 & 7.076 & 0.4 & 39.388 & 16.149 & 8.142 & 0.020 & 7.987 \\
\hline 0.6 & 40.629 & 19.908 & 10.907 & 0.034 & 8.967 & 0.6 & 52.827 & 21.659 & 10.907 & 0.034 & 11.618 \\
\hline 0.8 & 48.989 & 24.005 & 13.420 & 0.050 & 10.535 & 0.8 & 65.059 & 26.674 & 13.420 & 0.050 & 13.204 \\
\hline 1.0 & 56.570 & 27.719 & 15.763 & 0.068 & 11.887 & 1.0 & 76.467 & 31.351 & 15.763 & 0.068 & 15.523 \\
\hline 1.2 & 63.666 & 31.196 & 17.977 & 0.087 & 13.132 & 1.2 & 87.257 & 35.775 & 17.977 & 0.087 & 17.711 \\
\hline
\end{tabular}

growth efficiencies $(P / A b)$ were approximately 10 percentiles higher at high tide, ranging from $49 \%$ for juveniles to $53 \%$ for adult clams compared to a corresponding range of 37 to $42 \%$ at low tide. This increase, together with the behaviour of extending the siphons and valve gape, indicates the successful and immediate exploitation of the tidally induced improvement in food supply.

\section{DISCUSSION}

Venerupis corrugatus attained a positive potential for growth and reproduction $(P)$ when maintained in the laboratory in unfiltered seawater collected from its natural rock-pool habitat. Furthermore, when feeding on particulates in water collected at high tide, energy gain was significantly greater than on a diet of low-tide particles; for instance a clam of $1 \mathrm{~g} \mathrm{dry}$ wt increased its positive energy balance by $30.6 \%$. This coincided with an overall rise in the food source from 6.7 to $9.6 \mathrm{mg}$ dry wt $1^{-1}$ between low and high tide or, in energy terms, from 39.7 to $49.5 \mathrm{~J} \mathrm{l}^{-1}$.

It is of interest to place $P$ data $\left(\mathrm{J} \mathrm{h}^{-1}\right)$ within the timetable of the $13 \mathrm{~h}$ spring tidal cycle described by Stenton-Dozey \& Brown (1992) for the rock pool at Bloubergstrand. The cycle over which particle concentrations were measured involved an initial 4 h low-tide period followed by flooding of the pool for the next $5 \mathrm{~h}$, and then isolation for a further $4 \mathrm{~h}$. During this $13 \mathrm{~h}$ cycle we can estimate energy gain, based on $P$ data, at low tide as $11.9 \mathrm{~J} \mathrm{~h}^{-1} \mathrm{~g}^{-1} \times 8$ and at high tide, $15.5 \mathrm{~J} \mathrm{~h}^{-1}$ $\mathrm{g}^{-1} \times 5$ : this amounts to $172.7 \mathrm{~J}$, or if extrapolated to $24 \mathrm{~h}(\times 1.85), 318.8 \mathrm{~J} \mathrm{~d}^{-1} \mathrm{~g}^{-1}$. This represents a percentage change in body energy $\mathrm{d}^{-1}$ of $1.86 \%$ based on $17.14 \mathrm{~kJ} \mathrm{~g}^{-1}$ body dry wt (unpubl. data). This is a moderate estimate which falls within the range calculated for other bivalves fed natural diets (Stuart 1982, Stenton-Dozey 1989).

While it is clearly evident that the potential for growth and reproduction in Venerupis corrugatus is enhanced in the short period between tides, it is the mechanism by which this is achieved that needs addressing. In balancing energy gain and loss, it is the former which changed significantly between tides principally because at high tide, food intake increased when clearance rates doubled without a significant change in rates of respiration and excretion. When clearance rates increased, the siphons of $V$. corrugatus extended fully and the siphon aperture and valve gape increased to a larger degree than among clams feeding on low-tide particulates. This reaction has earlier been described by Riisgård \& Randlov (1981) and Riisgărd (1991). According to Jørgensen et al. (1988) and Jørgensen (1990) the degree of valve gape and area of siphon aperture vary with pumping rates from zero to a maximum rate characteristic of the fully open state. The maximum clearance rate of $V$. corrugatus compared favourably with that of $V$. pullastra when stimulated into the fully open state on a diet of algae (Møh- 
lenberg \& Riisgård 1979). Furthermore, Jørgensen (1990) states that environmental conditions that are compatible with the fully open state may be characterised as optimal. In this context conditions at high tide may be considered optimal for short-term exploitation of $V$. corrugatus growth potential.

Jorgensen (1990) disputes the widely held concept that water processing is energetically expensive and thus, to conserve energy, is physiologically controlled to ensure a constant intake of food over a wide range of particle concentrations (see references on p. $67 \& 68$ in Jørgensen 1990). Rather, pumping rates are considered to constitute physical consequences of the interfilament distances that are loosely coupled with valve gape. In this study the postural changes that accompanied clearance rate increases in Venerupis corrugatus, together with no significant increase in respiration rates, support Jørgensen's interpretation.

Clearance rate increases on the flood tide were associated with a $10 \%$ increase in the rock-pool silt load, a $25 \%$ rise in overail particle concentration and a shift in the particle size spectrum from a maximum diameter of $12 \mu \mathrm{m}$ at low tide to $23 \mu \mathrm{m}$ at high tide (Stenton-Dozey \& Brown 1992). Clearance rate increase was significantly linked to this shift in the size spectrum so that larger particles ( 8 to $13 \mu \mathrm{m}$ ) were cleared at maximum rates ( 3 to $4 \mathrm{l} \mathrm{h}^{-1} \mathrm{~g}^{-1}$ ) at high tide compared to smaller particles ( 5 to $9 \mu \mathrm{m}$ ) being filtered at top rates of 2 to $3 \mathrm{l} \mathrm{h}^{-1} \mathrm{~g}^{-1}$ at low tide. This, however, does not imply preferential clearance of larger particles. According to the principles of fluid mechanics (Jorgensen 1990), when water processing increases in response to denser suspensions, the shear forces between ciliary currents intensifies and particles most plentiful in these currents are indiscriminately directed towards the mouth. Nonetheless the end result was a $65 \%$ increase in gross ingestion. At the same time pseudofaeces production doubled so that in net terms, ingestion increased by $39 \%$.

Even though more pseudofaeces was released at high tide in response to an increase in particle concentration and silt content, the proportion of nutritious material (\% organics) filtered but then rejected differed little between tides, any variation being more a function of clam size than food quantity or quality (31 to $37 \%$ at low tide, 29 to $46 \%$ at high tide). Consequently particle sorting efficiency, derived from the proportions of organics in filtered and rejected material, also showed no marked differences between tides. Thus the process of organic enrichment of filtered material, i.e. pre-ingestive selection, does not appear to be influenced by the amount of material that has the potential for rejection. This is probably set by morphological constraints, such as the structure and size of the labial palps, food grooves and gills rather than physio- logical parameters. Indeed Jørgensen (1990) suggests that it is the nature of the spatial and temporal relationships between the surface currents along the gill filaments and the mucus strings across the filaments that determine the selective rejection of particles from mixed suspensions, the particle concentration of which exceeds the capacity of the digestive tract.

Material entering the digestive tract was absorbed with an efficiency of $49 \%$ at low tide and $41 \%$ at high tide, a small difference that was nonetheless significant. However, since the net ingested ration was 1.2 times that at low tide, the amount absorbed (IR $\times$ absorption efficiency), and ultimately $P$, were significantly greater at high tide. The intertidal change in absorption efficiency was thus insufficient to affect $P$, further demonstrating that particle clearance rate has primary influence on short-term growth potential.

Over the last decades filter feeding in bivalves has been considered to be physiologically regulated so as to secure a more or less constant ingestion rate at varying concentrations of suspended food particles (Winter 1978, Bayne \& Newell 1983). This aspect has recently been elaborated whereby feeding, metabolism and growth are seen to constitute controlled processes based on endogenous rhythms of gut fullness, gut passage time and absorption efficiency that are, in turn, correlated with the seasons (Hawkins et al. 1983, 1985, Bayne et al. 1984, 1987, Hawkins \& Bayne 1984, 1985). Jørgensen, in his recent review (1990) disputes these concepts, recognising that water processing is an autonomous process reflecting physical properties of the filter pump that are not subject to physiological regulation. Particle retention is viewed as being determined by the capacity of the pump and the ambient water quality and food concentration. Data in this paper are insufficient to support convincingly either argument although indirect evidence is in favour of Jørgensen's approach. Nonetheless it is important to realise that in future research the filter pump activity must be measured at full capacity to determine a bivalve's maximum growth potential before introducing variations in the environment (season, silt load, particle concentration) that may change this capacity.

Acknowledgements. Financial support was provided by the South African Foundation for Research Development.

\section{LITERATURE CITED}

Bayne, B. L., Hawkins, A. J. S. (1990). Filter feeding in bivalve molluscs: controls on energy balance. In: Mellinger, J., Truchot, J. P., Lahlou, B. (eds.) Animal nutrition and transport processes, Vol. 1, Nutrition in wild and domestic animals. Karger, Basel, p. 70-83

Bayne, B. L., Hawkins, A. J. S., Navarro, E. (1987). Feeding and digestion by the mussel Mytilus edulis L. (Bivalvia, 
Mollusca) in mixtures of silt and algal cells at low concentrations. J. exp. mar. Biol. Ecol. 111; 1-22

Bayne, B. L., Hawkins, A. J. S., Navarro, E., Iglesias, I. P. (1989). Effects of seston concentration on feeding, digestion and growth in the mussel Mytilus edulis. Mar. Ecol. Prog. Ser. 55: 47-54.

Bayne, B. L., Klumpp, D. W., Clarke, K. R. (1984). Aspects of feeding, including estimates of gut residence time, in three mytilid species (Bivalvia, Mollusca) at two contrast. ing sites in the Cape Peninsula, South Africa. Oecologia 64: $26-33$

Bayne, B. L., Newell, R. C. (1983). Physiological energetics of marine molluscs. In: Saleuddin, A. S. M. Wilbur, K. M. (eds.) The Mollusca, Vol. 4. Physiology, Part 1. Academic Press, New York, p. 407-515

Conover, R. J. (1966). Assimilation of organic matter by zooplankton. Limnol. Oceanogr. 11: 338-354

Coughlan, J. (1969). The estimation of filtering rate from the clearance of suspensions. Mar. Biol. 2: 356-358

Elliot, J. M., Davison, U. (1975). Energy equivalents of oxygen consumption in animal energetics. Oecologia 19: 195-201

Gnaiger, E. (1983). Calculation of energetic and biochemical equivalents of respiratory oxygen consumption. In: Gnaiger, E., Forstner, H. (eds.) Polarographic oxygen sensors: aquatic and physiological applications, Appendix C. Springer-Verlag, Berlin, p. 336-345

Griffiths, C. L., King, J. A. (1979). Some relationships between slze, food availability and energy balance in the ribbed mussel Aulacomya ater. Mar. Biol. 51: 1412-149

Griffiths, R. J. (1980). Natural availability and assimilation in the bivalve Choromytilus meridionalis (Kr.). Mar. Ecol. Prog. Ser. 3: 151-156

Hawkins, A. J S., Bayne, B. L. (1984). Seasona! variation in the balance between physiological mechanisms of feeding and digestion in Mytilus edulis (Bivalvia: Mollusca). Mar Biol. 82: 233-240

Hawkins, A. J S., Bayne, B. L. (1985). Seasonal variation in the relative utilisation of carbon and nitrogen by the mussel Mytilus edulis: budgets, conversion efficiencies and maintenance requirements. Mar. Ecol. Prog. Ser. 25: $181-188$

Hawkins, A. J. S., Bayne, B. L., Clarke, K. R. (1983). Co-ordinated rhythms of digestion, absorption and excretion in Mytilus edulis (Bivalvia: Mollusca). Mar. Biol. 74: 41-48

Hawkins, A. J. S., Salkeld, P. N., Bayne, B. L., Gnaiger, E., Lowe, D. M. (1985). Feeding and resource allocation in the mussel Mytilus edulis: evidence for time-averaged optimisation. Mar. Ecol. Prog. Ser. 20: 273-287

Jørgensen, C. B. (1990). Bivalve filter feeding: hydrodynamics, bioenergetics, physiology and ecology. Olsen \& Olsen, Fredensborg

Jørgensen, C. B., Larsen, P. S., Møhlenberg, F., Riisgảrd, H. U. (1.988). I he buvalve pump: properties and modelling. Mar. Ecol. Prog. Ser. 15: 283-292

Kiørboe, T., Mohlenberg, F, Nohr, O. (1981). Effect of suspended bottom material on growth and energetics in Mytilus edulis. Mar. Biol. 61: 283-288

Koroleff, F. (1976). Determination of ammonia. In: Grasshof, K. (ed.) Methods of seawater analysis. Verlag Chemie, Weinheim, p. 126-133

Lucas, M. I., Newell, R. C. (1984). Utilızation of saltmarsh grass detritus by two estuarine bivalves: carbohydrase activity of crystalline style enzymes of the oyster Crassostrea virginica (Gmelin) and the mussel Geukensia demissa (Dillwyn). Mar. Biol. Lett. 5: 275-290
Lucas, M. I., Newell, R. C., Shumway, S. E., Seiderer, L. J., Bally, R. (1987). Particle clearance and yeld in relation to bacterioplankton and suspended particulate availability in estuarine and open coast populations of the mussel Mytilus edulis. Mar. Ecol. Prog. Ser. 36: 215-224

Matthews, S., Lucas, M. I., Stenton-Dozey, J. M. E., Brown, A. C. (1989). Clearance and yield of bacterioplankton and particulates for two suspension-feeding infaunal bivalves, Donax serra Röding and Mactra lilacea Lam. J. exp. mar. Biol. Ecol. 125: 219-234

Mohlenberg, F., Riisgård, H. U. (1979). Filtration rate, using a new indirect technique, in thirteen species of suspensionfeeding bivalves. Mar. Biol. 54: 143-148

Navarro, E., Iglesias, J. I. P., Ortega, M. M. (1992). Natural sediment as a food for the cockle Cerastoderma edule (L.): effect of variable particle concentration on feeding, digestion and the scope for growth. J. exp. mar. Biol Ecol. 156 $69-87$

Newell, R. I. E., Jordan, S. J. (1983). Preferential ingestion of organic material by the American oyster Crassostrea virginica. Mar. Ecol. Prog. Ser. 13: 47-53

Newell, R. I. E., Langdon, C. J. (1986). Digestion and absorption of refractory carbon from the plant Spartina alterniflora by the oyster Crassostrea virginica. Mar. Ecol. Prog. Ser. 34: 105-115

Riisgård, H. U. (1991). Filtration rate and growth of the blue mussel Mytilus edulis Linnaeus, 1758: dependence on algal concentration. J. Shellfish Res. 10: 29-35

Riisgård, H. U., Randløv, A. (1981). Energy budgets, growth and filtration rates of Mytilus edulis at different algal concentrations. Mar. Biol. 61: 227-234

Seiderer, L. J., Newell, R. C. (1985). Relative significance of phytoplankton, bacteria and plant detritus as carbon and nitrogen resources for the kelp bed filter-feeder Choromytilus meridionalis. Mar. Ecol. Prog. Ser. 22: $127-139$

Stenton-Dozey. J. M. E. (1989). Physiology and energetics of the sandy-beach bivalve Donax serra Röding with special reference to temperature and chlorine tolerance. Ph.D. thesis, University of Cape Town

Stenton-Dozey, J. M. E., Brown, A. C. (1992). Clearance and retention efficiency of natural suspended particles by the rock-pool bivalve Venerupis corrugatus in relation to tidal availability. Mar. Ecol. Prog. Ser. 82: 175-186

Stuart, V. (1982). Absorbed ration, respiratory costs and resultant scope for growth in the mussel Aulacomya ater (Molina) fed on a diet of kelp detritus of different ages. Mar. Biol. Lett. 3: 289-306

Stuart, V., Klumpp, D. (1984). Evidence for food-resource partitioning by kelp bed filter-feeders. Mar. Ecol. Prog. Ser 16: $27-37$

Urban, E. R. Jr, Kirchman, D. L. (1992) Effect of kaolinite clay on the feeding activity of the eastern oyster Crassostrea virginica (Gmelin). J. exp. mar. Biol. Ecol. 160: $47-60$

Winter, J. E. (1978). A review on the knowledge of suspension-feeding in lamellibranchiate bivaives, wath special reference to artificial aquaculture systems. Aquaculture 13: $1-33$

Wright, R. T., Coffin, R. B., Ersing, C. P., Pearson, D. (1982) Fleld and laboratory measurements of bivalve filtration of natural marine bacterioplankton. Limnol. Oceanogr. 27 : $91-98$

Zar, J. H. (1984). Biostatistical analysis, 2nd edn. PrenticeHall, Englewood Cliffs

Manuscript first received: February 17, 1993

Revised version accepted: September 9, 1993 